\title{
Grounds For Allowing A Tax Deduction For Employee Share Incentives
}

\author{
Herman van Dyk, North-West University, South Africa
}

\begin{abstract}
Share-based payments have become a popular form of employee remuneration, largely due to its potential to address the agency problem, and are especially effective when made to senior employees. Accounting standards require companies to report share-based payments made to employees as expenses in their financial statements, but extant South African tax legislation does not permit a deduction, where shares are awarded, to serve as incentives for senior employees. This is due to the fact that the courts do not view the issue of a company's own shares as "expenditure". South African tax legislation presently contains a special tax deduction for shares awarded to employees, but this provision's restrictive requirements and low monetary limit is inadequate where the intention is to provide adequate incentives to senior employees in order to address the agency problem. The objective of this paper is to evaluate whether sufficient grounds exist, based on the principles of sound tax policy, for the legislature to enact a special tax deduction for share-based payments, that would serve as an adequate incentive to senior employees. The evaluation found that the current tax position infringes upon several principles of sound tax policy and that an intervention by the legislature is required.
\end{abstract}

Keywords: Share-Based Payments; Tax Deduction; Expenditure Actually Incurred; Sound Tax Policy Principles; Tax Symmetry

\section{INTRODUCTION}

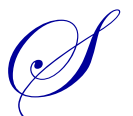

hare-based payments have become an increasingly popular form of employee remuneration, largely due to its ability to align divergences between the objectives of shareholders and employees. In South Africa, employees are taxed on employee benefits received both in cash and in kind ${ }^{1}$, and employees and directors are specifically taxed on equity instruments, such as shares and share options, when it vests ${ }^{2}$ in them. At the employer level, a deduction is ordinarily afforded for employee-related expenditure, in terms of the so-called general deduction provision of the Income Tax $\mathrm{Act}^{3}$ (De Koker \& Williams, 2011). Clegg and Stretch (2012) contend that this provision allows a deduction for expenditure incurred both in cash and in specie.

The above-mentioned treatment of employee benefits in the hands of employers and employees, is consistent with the general design of income tax systems, which entails that income tax is imposed on a tax base, referred to as taxable income. Taxable income is essentially a profit determined by including gross receipts and accruals in cash and in kind and deducting expenses necessary to generate such receipts or accruals (Bittker, 1968). If an employer therefore shifts valuable benefits to an employee, the employee is taxed thereon, while the employer is allowed a deduction from his taxable income for the valuable benefits surrendered.

\footnotetext{
${ }^{1}$ The definition of "gross income" in section 1 of the Income Tax Act taxes the "total amount "in cash or otherwise". Even before the definition included the words "in cash or otherwise", it was held in Lategan v CIR (1926) that the word 'amount' is not only restricted to cash but to all forms of property with a monetary value. Par $(c)$ to this definition specifically taxes amounts received or accrued in respect of services rendered or employment.

${ }^{2}$ Section 8C(1) of the Income Tax Act.

${ }^{3}$ Section 11(a) of the Income Tax Act.
} 
The general deduction provision of the Income Tax Act ${ }^{4}$ is found in section 11(a). This provision requires a taxpayer to inter alia have actually incurred "expenditure" or "losses" before it allows a deduction from his taxable income. Expenditure is distinguished from losses in that expenditure signifies a voluntary payment whereas the word loss denotes an involuntarily deprivation ${ }^{5}$. Since share-based payments are made voluntarily by employers, it only has to be considered if an employer actually incurs expenditure when shares are allocated to employees as remuneration.

In 2011, the Supreme Court of Appeal (SCA) was tasked to decide in the case of the Commissioner for South African Revenue Service v Labat Africa Limited (2011), whether the issue of a company's own share capital to pay for the acquisition of a trade mark constituted "expenditure actually incurred", as contemplated in the now repealed section $11(\mathrm{gA})$ of the Income Tax Act. The SCA held that the taxpayer merely received the trade mark as consideration for the issue of shares and that no money or assets were "expended" as required by the statute. It was further held that expenditure "requires a diminution (even if only temporary) or at the very least movement of the assets of the person who expends". Accordingly, the issue of shares to employees in exchange for services rendered would not qualify for a tax deduction in the hands of the employer, as it would not constitute "expenditure" as required by section $11(a)$.

International Financial Reporting Standard (IFRS) 2 requires an entity to report equity-settled share-based payments in its financial statements as an expense with a corresponding increase in equity (International Accounting Standards Board, 2012). The basis for conclusions to IFRS 2 contends that the expense arises from the consumption of resources, that is, the services received and that it is consistent with the IFRS definition of an expense contained within the Conceptual Framework for Financial Reporting (International Accounting Standards Board, 2012). The accounting treatment of share-based payments as an expense results in employers expecting a tax deduction (Mawani, 2003).

The taxation of share-based payments at the employer level clearly deviates from the general design of income tax systems, referred to above. The approach of taxing the recipient on the benefits received, but denying a deduction to the employer who parts with the benefits, has been criticised as being unfair (Ger, 2004) and contradictory to interpretations in other landmark cases, which could result in timing problems (Van Zyl, 2012). Van Eeden (2011) suggests that companies refrain from paying with shares altogether, while De Swardt (2008) and Gad and Strauss (2011) call for a legislative amendment to address this anomaly.

It is possible for employers to manufacture a deduction for share-based payments through adopting a different structure for the transaction. For example, employers could enter into an arrangement in terms of which employees receive cash grants, but are then required to purchase shares in the employer-company. Another alternative is to introduce an intermediate entity, such as a trust, to the transaction. The employer then incurs tax deductible personnel expenditure by making cash payments to the trust. The trust then purchases shares in the employer-company to hold on behalf of employee-beneficiaries. However, such structuring runs the risk of invoking the general anti-avoidance provisions of the Income Tax Act, which, if successfully applied, would nullify the deduction. Similarly, the deduction would also be disallowed if the transaction is regarded as simulated ${ }^{6}$.

Adam Smith famously penned the four maxims on which taxes in general should be based as equity, certainty, convenience and economic efficiency (Smith, 1776/1892). These maxims often form the basis of discussions into sound tax policy (for instance, Sneed, 1965; Lynn, 1976 and Brunori, 1997). The inequity and potential timing problems that stem from the outcome of the Labat judgment appear to infringe upon these principles.

\footnotetext{
${ }^{4}$ All references to the Income Tax Act refer to the South African Income Tax Act 58 of 1962.

${ }^{5}$ Refer to the judgment in Joffe \& Co (Pty) Ltd v Commissioner for Inland Revenue (1946).

${ }^{6}$ Refer to judgment in CSARS $v$ NWK Ltd (2011).
} 


\section{PROBLEM STATEMENT, RESEARCH QUESTION AND OBJECTIVES}

As a result of the Labat judgment, employees who receive shares as remuneration, are taxed thereon, whereas employers do not qualify for a deduction, unless they engage in alternative structuring, which will likely result in additional costs and attract scrutiny from the tax authorities. The problem statement addressed by this paper is that the tax position ensuing from the judgment appears to violate the principles of sound tax policy.

The research question that this paper aims to answer is whether sufficient grounds exist to justify an intervention by the legislature to enact a special tax deduction for employee share compensation?

In order to answer this research question, the following research objectives have been formulated:

- to evaluate the effectiveness of share-based employee compensation in achieving company objectives

- to analyse the Labat judgment and to consider its implications for employers who wish to engage in sharebased compensation

- to evaluate the implications of the Labat judgment against principles of sound tax policy.

\section{EFFECTIVENESS OF SHARE-BASED EMPLOYEE COMPENSATION IN ACHIEVING COMPANY OBJECTIVES}

According to Pendleton (2006), the main theoretical perspective for research into employee financial participation, is the theory of agency relationships, commonly referred to as "agency theory" or the "agency problem." Agency theory focuses on the problems that arise when the goals of the principal and the agent are in conflict (Eisenhardt, 1989).

The conflict that arises between the objectives of company directors (agents) and the objectives of shareholders (principals) in corporations where ownership is widely dispersed and, as a result, separated from control, was articulated as early as the eighteenth century by Smith (1776/1892). Agency theory assumes that agents would generally act to promote their own interests (Eisenhardt, 1989) and that they would not tend to the company's affairs with the same attentiveness that the principal would have done (Smith, 1776/1892).

Shareholders are generally concerned with maximising the value of the company and would expect their directors to actively pursue additional profitable ventures to further enhance value creation. They would also be inclined to minimise the consumption of company resources in the form of perquisites. In contrast, directors and employees would not devote the same effort to maximising the value of the company, since they would not derive the same benefit from it. They are more likely to act in self-interest and maximise the utility from their appointment, by appropriating the maximum allowable corporate resources in the form of their compensation packages and other benefits (Jensen \& Meckling, 1976).

Shareholders can ameliorate the agency problem and restrict divergences from their interests by monitoring actions and by establishing appropriate incentives for directors and staff (Jensen \& Meckling, 1976). Monitoring includes accountability to a board of directors (Eisenhardt, 1989), direct supervision (Pendleton, 2006), audits, formal systems of internal control and budget limitations (Jensen \& Meckling, 1976). Although monitoring actions are essential when ownership and control are separated, Pendleton (2006) observes that it can be expensive to implement and maintain and it can lead to a violation of trust between directors and shareholders, which can further exacerbate the agency problem. To mitigate this, Pendleton (2006) suggests a balanced mix of monitoring actions and incentives.

The incentive approach involves remunerating directors and employees, based on performance outcomes, such as by awarding cash bonuses and enabling staff to participate in share ownership plans. Hall and Liebman (1998) advocate share-based compensation as the answer to the agency problem, since this will result in employees participating in each change in company value. 
A number of respondents to a discussion paper on executive remuneration in the United Kingdom, raised the concern that compensation performance measures, such as total shareholder return and earnings per share, discourage directors from taking a long-term perspective. Respondents suggested that executive remuneration be simplified through share incentive schemes (Department for Business Innovation and Skills, 2012). When compared to other types of remuneration, share incentives encouraged employees to focus on a broader variety of outcomes, by providing incentives that encourage long-term perspectives (Pendleton, 2006).

Equity-based compensation, such as employee share purchase plans, is seen by many as an appropriate incentive to align the interests of directors and employees (Eaton \& Rosen, 1983; Bhagat, Brickley \& Lease, 1985). A study conducted by Frye (2004) found that companies that used greater amounts of equity-based compensation performed better. Smith and Watts (1983) found that share incentives were more likely to motivate executives than subordinate employees.

Share-based compensation also assists with the recruitment and retention of key employees (St-Onge, Magnan, Thorne \& Raymond, 2001), increased productivity and allowing start-up companies to compensate employees, without reducing their liquidity (Organisation for Economic Co-operation and Development, 2005).

The increased use of share-based compensation is another testament to its effectiveness. Share-based compensation has become so prevalent internationally that the International Accounting Standards Board deemed it necessary to issue a standard prescribing its accounting treatment in 2004 (International Accounting Standards Board, 2012). During 2000, all of the 100 largest companies in Canada used share-based compensation (Mawani, 2003). A content analysis of the latest annual reports of the ten largest companies listed on the Johannesburg Stock Exchange, based on market capital, revealed that they all used equity-settled share based payments (refer to Table 1).

Table 1. use of equity-settled share-based payments by the ten largest companies listed on the JSE

\begin{tabular}{clcc}
\hline Rank & \multicolumn{1}{c}{ Company } & $\begin{array}{c}\text { Latest annual } \\
\text { report }\end{array}$ & $\begin{array}{c}\text { Equity-settled share based payments reported } \\
\text { Yes or No }\end{array}$ \\
\hline 1 & British American Tobacco plc & 2013 & Yes \\
2 & SABMiller plc & 2014 & Yes \\
3 & Glencore Xstrata plc & 2013 & Yes \\
4 & BHP Billiton plc & 2013 & Yes \\
5 & Naspers Limited & 2014 & Yes \\
6 & Compagnie Financière Richemont SA & 2014 & Yes \\
7 & MTN Group Limited & 2013 & Yes \\
8 & SASOL Limited & 2013 & Yes \\
9 & Anglo American plc & 2013 & Yes \\
10 & Firstrand Limited & 2013 & Yes \\
\hline
\end{tabular}

The above observations indicate that the issue of equity instruments has become a popular form of employee remuneration, most likely due to its potential for addressing the agency problem. Companies who grant shares as remuneration perform better and have more productive employees. Equity-based compensation is also more effective in motivating senior employees than their subordinates. In spite of the obvious benefits associated with it, the lack of a tax deduction will likely affect companies' decision-making, to implement equity compensation schemes. Some companies may even decide to refrain from this practice altogether, as advised by Van Eeden (2011).

\section{TAX IMPLICATIONS OF THE LABAT JUDGMENT}

\section{Background facts of the case}

The taxpayer, Labat Africa Limited (formerly known as Acrem Holdings Limited), had concluded an agreement on 1 June 1999, in terms of which it purchased the entire business operations of Labat-Anderson (South Africa) (Proprietary) Limited for a purchase consideration of R120 million. The business operations acquired by the taxpayer included the "Labat-Anderson" trade mark which was valued at R44 million in the agreement. 
The agreement provided that the purchase consideration of R120 million would not be paid in cash, but discharged by issuing 133333333 shares in the taxpayer, at an issue price of 90 cents per share. The shares were issued to the seller on 15 June 1999. The market value of the shares was in excess of 90 cents per share on both the effective date of the agreement and on the date of the share allotment.

The taxpayer sought to claim a deduction from its taxable income during the 2000 year of assessment for the acquisition of the "Labat-Anderson" trade mark in terms of section 11(gA)(iii) of the Income Tax Act, which read as follows at the time:

"For the purposes of determining the taxable income derived by any person from carrying on any trade in the Republic, there shall be allowed as deductions from the income of such person so derived an allowance of any expenditure (other than expenditure which has qualified in whole or part for deduction or allowance under any of the other provisions of this section or the corresponding provisions of any previous Income Tax Act) actually incurred by the taxpayer in acquiring by assignment from any other person any such patent, design, trade mark or copyright or in acquiring any other property of a similar nature or any knowledge essential to the use of such patent, design, trade mark, copyright or other property or the right to have such knowledge imparted such invention, patent, design, trade mark, copyright, other property or knowledge, as the case may be, is used by the taxpayer in the production of his income" (own emphasis).

The expenditure actually incurred, qualified for a deduction equal to the amount divided by the number of years, that represented the probable duration of use of the trade mark or four percent of the amount, whichever was greater (section $11(\mathrm{gA})(\mathrm{iii})(a a)(\mathrm{A})$.

The Commissioner for the South African Revenue Service (SARS) disallowed the deduction in Labat's assessment on the grounds that the taxpayer did not expend any monies or assets in discharging its obligation, and accordingly did not actually incur expenditure as required by section $11(\mathrm{gA})$. The Commissioner's contention was based on a judgment by the Tax Court ${ }^{7}$ (ITC 1783, 2004) where it was held that "[a]n allotment or issuing of shares by a company does not in any way reduce the assets of the company..." and it was accordingly held that the issue of a company's own shares does not constitute expenditure incurred by that company.

\section{Taxpayer's Appeal to the Tax Court}

The taxpayer, Labat Africa Limited, was dissatisfied with the Commissioner's disallowance of the deduction and appealed to the Tax Court (ITC 1801, 2005). The taxpayer contended that expenditure was actually incurred when an unconditional legal obligation had been incurred and that the discharging of the obligation was irrelevant. The taxpayer's contention was based on judgments in Edgars Stores Ltd v Commissioner for Inland Revenue (1988) and Nasionale Pers Beperk v Kommissaris van Binnelandse Inkomste (1986).

The Commissioner argued that, because the taxpayer was required in terms of the agreement to discharge its obligation by issuing its own shares, no expenditure was actually incurred. The taxpayer submitted that the Commissioner's contention was in conflict with a number of high authority judgments.

The taxpayer cited three English cases which dealt with barter transactions where "payment" was made by a company issuing its own shares. In Osborne v Steel Barrel Co Limited (1942), it was held that when a company issued its own shares as payment for stock, it gave up the right to call on the holder for payment for the shares and this represented a consideration other than cash. Similarly, in Craddock v Zevo Finance Co Limited (1944) ${ }^{8}$, it was held that a company's own shares issued in exchange for trading assets constitute "genuine consideration". In Stanton (Inspector of Taxes) v Drayton Commercial Investment Co Limited $(1982)^{9}$, it was held that the agreed issue price of the company's own shares constituted consideration for assets acquired by the company and the company was entitled to a deduction of such amount. The taxpayer also referred to a South African case, Lace Proprietary

\footnotetext{
${ }_{8}^{7}$ Judgments of the Special Income Tax Court, often referred to as the Tax Court only apply inter partes (South African Revenue Service, 2014).

${ }^{8}$ This judgment was subsequently upheld by the House of Lords.

${ }^{9}$ This judgment was subsequently upheld by the House of Lords. 
Mines Limited $v$ Commissioner for Inland Revenue (1938), where a company sold mineral rights and the agreed consideration was a number of shares in the company. The Appellate Division held that the company had to include the actual value of the shares received for income tax purposes. Labat contended that this decision confirmed that an agreement by a company to issue its own shares constituted consideration, otherwise the selling company would not be taxed on the shares received.

Based on the arguments raised above, the Tax Court held that the taxpayer was only required to incur an unconditional legal obligation in order to meet section 11 $(\mathrm{gA})$ 's requirement of "expenditure actually incurred". It was further held that an undertaking by a company to issue its own shares constituted real consideration. The court held that the decision in ITC 1783 was clearly wrong. Consequently, the taxpayer's appeal was upheld and the Commissioner was ordered to adjust the tax assessment accordingly. The court also cited to the neutrality principle of taxation in support of its judgment, stating that "tax issues should not unnecessarily complicate or frustrate ordinary commercial transactions".

\section{Commissioner's Appeal to the High Court}

The Commissioner appealed to the North Gauteng High Court and judgment was handed down during December 2009 by Sapire AJ (Commissioner for South African Revenue Service v Labat Africa Limited, 2009). The judgment confirmed that the taxpayer was only required to incur an unconditional legal obligation to meet the deductibility requirement, which was not dependent upon the making of payment. It was further held that if the agreement for the acquisition of the trade mark had instead been that the seller would purchase an agreed number of the unissued shares of the purchaser at an agreed price and that such proceeds of issue would be used to pay for the trade mark, the transaction would undoubtedly constitute expenditure. The court found that it was unable to distinguish between such alternative construction of the transaction and the actual transaction. The appeal was accordingly dismissed with costs and the judgment by the Tax Court was upheld.

\section{Commissioner's Appeal to the Supreme Court of Appeal}

Following the North Gauteng High Court's dismissal of his appeal, the Commissioner appealed to the Supreme Court of Appeal (SCA), where judgment was delivered by Harms AP during September 2011 (Commissioner for South African Revenue Service v Labat Africa Limited, 2011).

The SCA held that the lower courts had focused on the "actually incurred" part of section $11(\mathrm{gA})$, whereas they should have considered the meaning of the word "expenditure" that was also contained within the provision. The lower courts had correctly reasoned from the Edgars Stores and Nasionale Pers cases that the words "actually incurred" only required the taxpayer to incur an unconditional legal obligation and that Labat had done so by undertaking to issue the shares. However, the SCA held that the words "obligation" and "expenditure" were not synonyms. Section $11(\mathrm{gA})$ required a taxpayer to actually incur expenditure, in other words, the unconditional legal obligation had to be discharged by means of "expenditure". The court followed the literal approach to interpret the word, which means "the action of spending funds; disbursement or consumption; and hence the amount of money spent". The SCA held that in the context of the Income Tax Act, expenditure would also include the disbursement of other assets with a monetary value. Expenditure, accordingly, required at least a temporary reduction in or movement of assets of the party who expended. Consequently, the issue of a company's own shares did not constitute expenditure.

Harms AP also commented on the taxpayer's reliance on the English judgments (refer to the appeal to the Tax Court above). The SCA agreed that the issue of a company's own shares for the acquisition of assets amounted to 'consideration'. However, it was held that this fact was never a point of contention. The statutory provision required the taxpayer to actually incur "expenditure" and no reference was made to "consideration". The English judgments were accordingly ruled to be irrelevant to the present case.

The SCA judgment further rejected the "set-off argument" advocated by the High Court on behalf of the taxpayer. This argument entailed that if the agreement had instead been that the seller would subscribe to shares in the taxpayer and the taxpayer would use the proceeds from the share issue to purchase the trade mark, it would 
constitute expenditure. The SCA held that since there was no indication that the agreement between the parties was in any way simulated, the actual terms of the agreement were conclusive. The fact that the agreement could have been structured differently was irrelevant.

The SCA also responded to the taxpayer's submission that serious anomalies would occur if the issue of a company's own shares was not regarded as expenditure. The taxpayer's argument was based on the fact that the recipient of the shares was treated as having received consideration and was potentially liable to tax thereon, whereas the issuing company was not afforded a deduction because it did not incur expenditure. The SCA held that tax legislation was known for containing a number of anomalies and inconsistencies, but these were matters to be addressed by the legislature.

Accordingly, the Commissioner's appeal was upheld and the taxpayer was not afforded a deduction in terms of section 11 $(\mathrm{gA})$, because the issue of its own shares did not constitute expenditure.

Tax implications ensuing from the Labat judgment

In consequence of the SCA's judgment in the Labat case, if a taxpayer-company discharges an obligation by issuing its own shares instead of disbursing cash or other assets, it will not be allowed a tax deduction where the relevant provision requires the taxpayer to incur 'expenditure'. The Income Tax Act does, however, contain two special provisions where a company is deemed to incur expenditure when 'paying' with its own shares.

\section{Acquisition of Assets in Exchange for Shares: Section 40CA}

During 2004, some four years after the year of assessment relating to the dispute in the Labat case, a special provision was enacted, that deemed a company to incur expenditure where an asset was acquired, in exchange for the company's shares (section 24B(1)). This amount of expenditure was deemed to be equal to the lesser of the market value of the asset and the market value of the shares issued. Since 1 January 2013, this provision was substituted with the largely similar section 40CA, which also deems a company to incur expenditure when an asset ${ }^{10}$ is acquired in exchange for the company's shares. Section 40CA deems the company to have incurred expenditure equal to the market value of the shares issued and the market value of the asset is not considered (section $40 \mathrm{CA}(a)$ ). Where a company 'pays' for trading stock by issuing its own shares, the company will effectively be able to deduct the market value of the shares issued from its taxable income. When a company acquires a capital asset in the same manner, the market value of the shares issued will be deductible from the proceeds upon subsequent disposal of such asset for capital gains tax purposes. The Explanatory Memorandum to the Revenue Laws Amendment Bill (2004) explains that prior to the enactment of the special provision, the so-called 'zero principle' applied, that is a company did not incur expenditure when issuing shares for the acquisition of assets and that support for the zero principle is found in case law. ${ }^{11}$ The Explanatory Memorandum justifies the inclusion of the special provision by describing the zero principle as a "significant hindrance to company formations and other forms of share financing" (p. 56) and "in contrast to widespread international practice" (p.56). The position before the special provision is also referred to as problematic, because the transferor of the asset in such a transaction is liable to tax on the transfer (National Treasury, 2004). The inclusion of the special provision will not allow a tax deduction for shares issued as remuneration to employees, since no asset is acquired.

\section{Equity Shares Granted to Employees in a Broad-Based Employee Share Plan: Section 11(La)}

Section 11(lA) allows a special deduction for the market value of qualifying equity shares granted to an employee in terms of a broad-based employee share plan as contemplated in section $8 \mathrm{~B}$. The deduction is limited to R10 000 per employee per year of assessment (section $11(l \mathrm{~A})$ ) and at least $80 \%$ of the company's permanent fulltime workforce must be entitled to participate (section 8B(3)). Employees are not taxed when the shares are granted

\footnotetext{
${ }^{10}$ Section 40CA refers to an 'asset' as defined in paragraph 1 of the Eighth Schedule to the Income Tax Act. This ambit of this definition is wide and includes capital assets and trading stock, whether movable or immovable, tangible or intangible.

${ }^{11}$ Presumably ITC 1783 where judgment was delivered during February 2004.
} 
to them (section $10(1)(n \mathrm{C})$ ), but are liable to tax upon the subsequent disposal of the shares. ${ }^{12}$ The market value of shares granted to a single employee is limited to R50 000 over a five-year period. Smith and Watts (1983) have found that share-based compensation is more effective at motivating senior employees than their subordinates. The broad-based requirement and relatively low monetary deduction afforded by section $11(l \mathrm{~A})$ renders this special provision unusable where the objective is to appropriately incentivise senior employees or executives.

Employers who wish to implement share participation schemes, that do not meet the restrictive requirements of section 11(lA), would therefore not qualify for a tax deduction. Such a scheme would also increase the company's effective tax rate for financial reporting purposes. For example, if a company has a reported profit before tax of 100 determined after a non-tax deductible share-based payment expense of 10 was subtracted for accounting purposes, the company's effective tax rate would be $30.8 \%$ compared to a statutory income tax rate of $28 \%$ (refer to Table 2 ).

Table 2. Illustration of effect of non-deductible share-based payments on effective company tax rate

\begin{tabular}{lc}
\hline Accounting profit before tax (A) & 100 \\
Add back: non-deductible share-based payment expense & 10 \\
Taxable income & 110 \\
Corporate income tax at statutory rate of $28 \%$ (B) & 30.8 \\
Effective tax rate (B/A) & $30.8 \%$ \\
\hline
\end{tabular}

The adverse tax treatment of share-based payments at the employer level is certain to result in any employers refraining from this form of employee remuneration.

\section{Alternative Structuring of Employee Share Compensation Schemes to Qualify for a Tax Deduction}

Instead of a direct issue of shares to employees, employers could structure share remuneration transactions in a different manner. For example, the employer can enter into an arrangement in terms of which employees are initially paid an amount in cash remuneration, but then use such amount to subscribe to shares in the company. It is submitted that the cash remuneration paid as part of this structure will constitute "a temporary reduction or movement of assets of the party who expends", as inferred in the Labat judgment, and would therefore constitute "expenditure". Taken as a whole, the two steps of this structure would have the same effect on the company as if the shares had been directly issued to the employees, but because there was a temporary movement of cash, it qualified for a deduction.

Another way of structuring the transaction is to introduce a trust as an intermediate entity to hold the shares on behalf of employees in a custodial capacity. The employer incurs deductible personnel expenditure by making cash payments to the trust ${ }^{13}$. The trust then purchases shares in the employer-company to hold and administer for the benefit of the employees.

However, such alternative structures are not void of tax risks. If any of the above-structured constitutes an "impermissible avoidance arrangement", as defined in section $80 \mathrm{~L}$ of the Income Tax Act, the revenue authorities have the power to, inter alia, determine the tax consequences, as if the transaction has not been carried out or to disregard or combine any parts of the transaction.

Another potential tax risk is that a court may give effect to the substance of a transaction, rather than its form (De Koker \& Williams, 2011). In Erf 3183/1 Ladysmith (Pty) Ltd and Another v Commissioner for Inland Revenue (1996) a taxpayer had entered into several agreements in a form which obscured the true substance of the arrangement as a whole. The court held that all the agreements had to be considered in context of one another in

\footnotetext{
${ }^{12}$ If the shares are sold within five years, the gain made on the shares are fully liable to tax. If shares are sold after five years, only a third of the gain is liable to tax in terms of capital gains tax legislation.

${ }^{13}$ It is submitted that the trust will not be taxed on such payments received since they are 'fortuitous' and 'not designedly sought for and worked for' and therefore capital in nature. Refer to the judgment in Commissioner for Inland Revenue $v$ Pick ' $n$ Pay Employee Share Purchase Trust (1992).
} 
order to determine its overall effect. The alternative structures referred to above, could fall foul of this principle if each step was considered in context of the other steps.

Similarly, the deduction enabled by the alternative structure would also be disallowed if it was regarded as a simulated transaction. Authority for this is found in the Commissioner for South African Revenue Service $v$ NWK Ltd (2011) where it was considered how the court had to determine the true intention of a party to a transaction that appeared to be simulated. The principle that taxpayers were free to structure transactions in the most tax-efficient manner, was confirmed. However, the court held that "there is something wrong with dressing up or disguising a transaction to make it appear to be something that it is not".

In summary, if an employer-company wishes to alleviate the agency problem by issuing an adequate amount of shares to its senior employees, it will not be allowed a tax deduction, unless the transaction is structured to ensure that a temporary movement of the employer's assets takes place. Such structuring runs the risk of scrutiny by the tax authorities, which could result in increased taxes, penalties and consulting fees, as well as the nuisance of dispute resolution processes and potential litigation.

\section{EVALUATION OF IMPLICATIONS OF LABAT JUDGMENT AGAINST PRINCIPLES OF SOUND TAX POLICY}

The SCA was essentially concerned with the meaning of the word "expenditure" when it considered the Labat case. The court followed a literal approach to interpret the word and its ordinary meaning was attributed to it. Since the issue of a company's own shares did not result in any cost to the company or movement of its assets, it was established that a share issue did not constitute "expenditure". The fact that the judgment resulted in anomalies or inconsistencies could not be taken into account when interpreting the word. Anomalies and inconsistencies are matters for the legislature to attend to. De Swardt (2008) and Gad and Strauss (2011) have called for an intervention by the legislature to address such anomalies and inconsistencies.

In 1776, Adam Smith penned the four maxims by which to evaluate a tax system (Brunori, 1997). In brief, these maxims are equity, certainty, convenience and economic efficiency (Smith, 1776/1892) and are advocated by many as the principles of sound tax policy (Blough, 1955; Lynn, 1976; Reese, 1980 and Brunori, 1997).

The final part of this paper will attempt to evaluate the extant tax treatment of employee share remuneration in South Africa against the principles of sound tax policy.

\section{Principle of Equity}

Smith (1776/1892) penned the equity principle as the first of his four maxims of taxes in general. While the tax system in general should comply with this principle, equity is not a consideration when the courts are charged with interpreting tax legislation. When the wording of legislation is unambiguous and clear, the court must apply the literal meaning of the words and attribute to it its ordinary meaning, unless otherwise defined in the relevant statute (De Koker and Williams, 2011). In Cape Brandy Syndicate v Inland Revenue Commissioner (1921) the court held that "[t]here is no equity about a tax...One can only look fairly at the language used." Since neither section $11(g A)$ nor section 11(a) of the Income Tax Act is unclear or appears to contain an ambiguity, it is contended that the SCA was correct in applying the literal approach to the meaning of the word "expenditure". The fact that the literal meaning results in hardship for the taxpayer cannot be taken into consideration by the court in construing the provision (Partington $v$ The Attorney General, 1869). If an inequity exists in the tax system, it is the task of the legislature to address it through the enactment of appropriate amendments.

The principle of equity in a system of taxation is often discussed from one of two perspectives, vertical equity and horizontal equity (Institute on Taxation and Economic Policy, 2012). Vertical equity is described as the manner in which taxpayers, with dissimilar abilities to pay, must be treated (Sneed, 1965). Vertical equity is often achieved through progressive tax systems, such as the rates of income tax applicable to natural persons in South Africa, that range from zero to forty percent, imposing higher taxes on upper-income taxpayers. 
Horizontal equity calls for equal tax treatment of all taxpayers in equal circumstances (Musgrave, 1990). This principle is also enshrined in section 9 of the Constitution (1996), which guarantees everyone the right to equal benefit of the law. Failure to adhere to the principle of horizontal equity undermines public support for a tax system, makes it difficult to defend and reduces the inclination of taxpayers to submit honest tax returns (Institute on Taxation and Economic Policy, 2012). Accordingly, the current tax treatment of employee share remuneration will be evaluated against the principle of horizontal equity.

The present system of imposing tax on the recipient of share-based payments, while disallowing a deduction to the issuing company, has been criticised as being anomalous, incongruous and leading to inequity (Ger, 2004; Gad \& Strauss, 2011; Brincker, 2011). This criticism is largely aimed at the fact that the present system does not achieve tax symmetry.

Tax symmetry requires that the two parties to a transaction be treated "equal and opposite" (Bradford, 1995). Therefore, at the same time that one party is afforded a deduction, the other party should have an equal inclusion (Bradford, 1995). The lack of tax symmetry results from the different wording of the legislative provision imposing income tax on share-based payments received, compared to the legislative provision that would potentially allow a deduction to the issuer of the shares.

The definition of "gross income" in section 1 of the Income Tax imposes income tax on "the total amount, in cash or otherwise, received by or accrued to or in favour of..." a taxpayer (own emphasis). The phrase "in cash or otherwise" denotes that taxpayers are not only taxed on cash amounts received, but also on amounts received in kind. Even before this phrase was included in the definition, Watermeyer J held the following in Lategan WH $v$ Commissioner for Inland Revenue, 1926): “...the word "amount” must be given a wider meaning, and must include not only money, but the value of every form of property earned by the taxpayer, whether corporeal or incorporeal, which has a money value." In addition, section $8 \mathrm{C}(1)$ specifically taxes employees and directors upon the vesting of equity instruments during a year of assessment. The amount taxed is the market value of the equity instruments reduced by any consideration paid by the employee or director. It is therefore evident that taxpayers who receive shares or other equity instruments in exchange for services rendered, are liable to tax thereon.

A taxpayer who receives shares in exchange for services, is taxed even if he derives no benefit from allotment. In Ochberg $v$ CIR (1931), the taxpayer owned virtually all ${ }^{14}$ of the issued shares in the Airton Timber Company Ltd. The company then allotted additional shares to the taxpayer in consideration for services rendered to the company. The taxpayer argued that he could not be taxed on the shares he had received, as he had derived no benefit from the additional issue. The taxpayer's argument was based on his antecedent position, that is he already owned essentially the whole of the company and that the additional issue had a negligible impact on his position ${ }^{15}$. The court held that the question whether the taxpayer derived a benefit was not relevant and, accordingly, he was taxed on the objective value of the shares allotted to him.

In contrast, section $11(a)$, the provision that would potentially allow a deduction for equity instruments awarded to senior employees and executives, refers to "expenditure" instead of "amount". Based on the judgments in the Lategan, ITC 1783 and Labat cases, it is clear that "amount" is a much broader term which includes anything with a money value. In order to incur "expenditure", there must be a movement of the taxpayer's assets, which is not achieved when a company issues its own shares in exchange for services. The use of different words results in an asymmetrical tax system with respect to share-based payments. In addition, there is no comparative deduction provision at the employer level for the taxing section $8 \mathrm{C}$ at the employee level.

The expectation of tax symmetry presumably originates from a number of special provisions in the Income Tax Act, where the person paying an amount is allowed a tax deduction, provided that the recipient is taxed thereon. For example, section 11(cA) allows a deduction for compensation paid in respect of restraint of trade made to a natural person, labour broker or personal service provider and the Act specifically taxes such compensation in the

\footnotetext{
${ }_{15}^{14}$ The taxpayer's interest in the company was $99.88 \%$ before the transaction.

${ }^{15}$ The taxpayer's interest increased to only $99.94 \%$ after the transaction. The transaction increased his interest by a mere $0.06 \%$. 
hands of an employee, labour broker or personal service provider who receives it (paragraphs $(c \mathrm{~A})$ and $(c \mathrm{~B})$ to the definition of 'gross income' in section 1).

Similarly, a person paying alimony and maintenance under a divorce order instituted before 21 March 1962 , is allowed a deduction for such payments in terms of section 21 , whereas the recipient is taxed thereon in terms of the special inclusion in paragraph $(b)$ of the definition of "gross income" in section 1. If the divorce order was instituted after 21 March 1962, the person paying the amount is not allowed a deduction, but the recipient is also not liable to tax on the amount by virtue of the exemption in section 10(1)(u).

Apart from the tax symmetry argument, further criticism against the current position is that a company that pays for services by issuing its own shares forfeits the right to receive cash consideration in respect of the issue (Meyerowitz, 2006), and that the allotment of a company's own shares in discharging obligations has value in the business world (Brincker, 2011). The Organisation for Economic Co-Operation and Development (2005) states that a company that remunerates an employee by issuing an equity instrument bears an "economic cost" equivalent to what an outside investor would have paid for it. The fact that the issue of a company's own shares as a quid pro quo for services rendered does not qualify for a deduction, would certainly impede this prevalent commercial practice.

The Explanatory Memorandum to the Revenue Laws Amendment Bill (2004) cited the achievement of tax symmetry as justification for deeming the issue of a company's own shares in exchange for the acquisition of assets to be 'expenditure' (National Treasury, 2004). The same document stated that the law, before the deeming provision, was a 'significant hindrance to company formations and other forms of share financing' and 'in contrast to widespread international practice' (National Treasury, 2004, p.56).

It is contended that the same arguments can be submitted in favour of deeming a company's own equity instruments, issued as employee remuneration, to be 'expenditure'. Firstly, the tax treatment of shares awarded to senior employees is clearly asymmetrical. Secondly, the first part of this paper observed that share remuneration paid to senior employees was an effective remedy to the agency problem and could result in increased firm and employee performance. It has also been noted that a company paying for services with its own shares, bears an economic cost for such shares, which have real commercial value. The absence of an adequate tax deduction is therefore also a significant hindrance to the benefits associated with this type of remuneration. Lastly, the majority of OECD member countries allow some form of tax deduction at the corporate level for equity-based compensation (Organisation for Economic Co-operation and Development, 2005). The introduction to this paper has indicated the practice of international accounting standards to treat such remuneration as an expense. One could therefore argue that the current law in South Africa is also in contrast to 'widespread international practice'.

Extant South African legislation currently allows a tax deduction where a company purchases trading stock and discharges its obligation by issuing its own shares. However, should a company opt to remunerate its employees by issuing shares instead of paying cash, the company would not qualify for a tax deduction. This patent discrimination clearly infringes upon the principle of horizontal equity.

\section{Principle of Certainty}

According to Smith (1776/1892), taxes levied upon taxpayers ought to be certain and not arbitrary. He emphasised that certainty was of such importance that a considerable degree of inequity could be tolerated before a tax system contained a small degree of uncertainty.

The present tax position appears to give rise to two uncertainties. The first uncertainty relates to distinguishing between the concept of incurring an obligation and the settlement or payment thereof. Van Zyl (2012) is of the opinion that in the Labat case, the SCA improperly interpreted expenditure to mean actual payment, which contradicts the interpretation in the Edgars Stores and Nasionale Pers cases. Ger (2004) shares a similar view with respect to the judgment in the ITC 1783 case.

It was confirmed in Caltex Oil (SA) Ltd v Secretary for Inland Revenue (1975) and in the Edgars Stores and Nasionale Pers cases that "actually incurred" does not mean "actually paid". A taxpayer is only required to incur an 
unconditional legal obligation in order to qualify for a deduction. In Labat, the SCA held that "expenditure" and "obligation" are not synonyms and that a taxpayer is required to discharge the obligation by means of "expenditure". Van Zyl (2012) states that this causes two inconsistent interpretations of the so-called general deduction formula.

Another established principle is that expenditure must be deducted in the year of assessment incurred and may not be claimed in a subsequent year (Concentra (Pty) Ltd $v$ CIR, 1942). A problem could arise if, for example, a taxpayer incurs an unconditional legal obligation for services rendered during the 2014 year of assessment, but then does not discharge the obligation by the end of 2014. If the taxpayer fails to claim the deduction during 2014, it will be forfeited. Should the taxpayer deduct the amount in 2014, but in 2015 decide and agree with the counterparty to extinguish the obligation by issuing its own shares, the deduction already claimed in the preceding year of assessment will be void per the Labat judgment.

The second uncertainty pertains to the set-off argument advocated by the High Court on behalf of Labat Africa Limited. Instead of issuing shares for services directly, the taxpayer can pay cash and agree with the recipient to apply the proceeds to subscribe to its shares in the taxpayer. This would result in a "temporary diminution" or "movement" of the taxpayer's assets as inferred in the SCA judgment. According to Brincker (2005), there is a risk that the court may look at the arrangement as a whole and decide that the intention was never to part with cash, but to issue shares.

\section{Principle of Convenience}

The third maxim, the principle of convenience, requires that taxes should be levied at the time and in the manner which is most convenient to the taxpayer (Smith, 1776/1892).

The absence of an adequate deduction for equity-based compensation forces employers to adopt complex alternative transaction structures, such as the introduction of intermediate entities, to facilitate a tax deduction. Such structures would involve uncertainty, additional cost and effort and scrutiny from revenue authorities, which would all cause substantial inconvenience to the employer, who wishes to engage in this form of employee financial participation.

\section{Principle of Economic Efficiency}

The fourth and final maxim requires that taxes "keep out of the pockets of the people as little as possible over and above what it brings into the public treasury...."(Smith, 1776/1892, p.652). This principle requires that the collection cost of taxes should be minimised as far as possible and that taxes should not interfere with business decisions (Smith, 1776/1892).

According to the OECD, an efficient tax treatment of equity-based compensation schemes is a treatment that is entirely neutral with respect to the choice of awarding shares or paying cash compensation and that tax neutrality is not achieved in the absence of a deduction for equity compensation (Organisation for Economic Cooperation and Development, 2005). The present tax system allows a full deduction of cash remuneration and other benefits paid to employees. However, should a company wish to take advantage of the benefits associated with share-based payments, and issue an adequate number of shares to serve as incentives to senior employees, it will not be allowed a tax deduction. The lack of a tax deduction increases companies' effective tax rate and will likely result in some employers refraining from the practice of equity-based compensation.

As discussed above, employers could structure share-based payment schemes in a different manner to achieve a tax deduction. The lack of an adequate deduction forces taxpayers to complicate a simple transaction and adopt structures which are less transparent. This is likely to involve revenue authorities in audits, dispute resolution processes and litigation, which are often protracted and cumbersome. The dispute in the Labat case, where the transaction contained no abnormal or opaque elements, related to a transaction effected during the 2000 year of assessment. The dispute was heard by the Tax Court in 2005, which ruled in the taxpayer's favour. The Commissioner's unsuccessful appeal to the High Court was heard in 2009 and the matter was only concluded towards the end of 2011, when the SCA handed down its judgment, some eleven years after the tax year in which 
the transaction occurred. A tax position that is likely to impose such a considerable administrative burden upon revenue authorities would hardly promote keeping revenue collection costs within the international benchmark of $1 \%{ }^{16}$.

In summary, the current tax position appears to breach all four maxims to some degree. The current treatment is inequitable, because it allows a deduction for trading stock purchased by issuing a company's own shares, but does not allow deduction when paying for services by issuing a company's own shares. It is uncertain because it contradicts existing interpretations of the general deduction formula and the treatment of the so-called setoff transaction is also unclear. It is also inconvenient and inefficient because it has the potential to interfere with the economic decisions of taxpayers and to increase the cost of revenue collection.

According to Sneed (1968) and Surrey and Brannon (1968), there is often a conflict between achieving equity and achieving the last three of Smith's maxims, which are collectively referred to as principles of practicality or simplicity. However, the current tax position appears to infringe upon all of the principles of sound tax policy.

\section{CONCLUSION}

The use of share-based employee remuneration has become increasingly popular, most likely due to its potential for addressing the agency problem and increased employee productivity, resulting in better firm performance. Share-based payments are most effective when made to senior employees. Despite the benefits associated with share-based remuneration and international practice to the contrary, extant South African tax legislation does not allow a tax deduction where the objective is to provide adequate incentives to senior employees. This is due to the fact that the courts do not view the issue of a company's own shares as "expenditure". The existing special deduction for share-based payments is inadequate where the intention is to provide sufficient incentives to senior employees due to its restrictive requirements and low monetary limit.

The question that this paper has undertaken to answer is whether sufficient grounds exist, based on the principles of sound tax policy, to justify the legislature to enact a special tax deduction for employee share compensation. It was found that the current tax position of not permitting an adequate tax deduction breaches established principles of sound tax policy. The inequity, uncertainty, inconvenience and inefficiency created by the current system require remedial action by the legislature.

\section{AUTHOR INFORMATION}

Herman van Dyk is a Senior Lecturer in the Programme for Taxation at the Potchefstroom Campus of the NorthWest University in South Africa. He is a qualified Chartered Accountant (South Africa) and Registered Auditor.

\section{REFERENCES}

Bhagat, S., Brickley, J.A., \& Lease, R.C. (1985). Incentive effects of stock purchase plans. Journal of Financial Economics, 14(1), 195-215.

Bittker, B.I. (1968). Comprehensive income taxation: a response. Harvard Law Review, 81(5), 1032-1043.

Blough, R. (1955). The history and philosophy of taxation. Williamsburg: College of William and Mary.

Bradford, D.F. (1995) Fixing Realization Accounting: Symmetry, Consistency and Correctness in the Taxation of Financial Instruments. 50 Tax L. Review at 743.

Brincker, E. (2005). Taxation Principles of Interest and Other Financing Transactions. Lexisnexis.

Brincker, E. (2011). The issue of shares does not constitute an expense for tax purposes. DLA Cliffe Dekker Hofmeyr Tax Alert.

Brunori, D. (1997). Principles of tax policy and targeted incentives. State and Local Government Review. 29(1), 50 61.

Caltex Oil (SA) Ltd v Secretary for Inland Revenue. (1975). (1) SA 665 (AD).

${ }^{16}$ The current cost of revenue collection marginally exceeds the international benchmark of $1 \%$. This ratio was $1.11 \%$ in $2011 / 2012$ and $1.07 \%$ in 2012/2013 (National Treasury, 2013) 
Cape Brandy Syndicate v Inland Revenue Commissioner. (1921). 1 KB 64.

Clegg, D. \& Stretch, R. (2012). Income Tax in South Africa. Lexisnexis.

Commissioner for Inland Revenue v Pick 'n Pay Employee Share Purchase Trust. (1992). (4) SA 39 (AD).

Commissioner for South African Revenue Service v Labat Africa Limited. (2009). A206/06.

Commissioner for South African Revenue Service v Labat Africa Limited. (2011). (669/10) [2011] ZASCA 157.

Commissioner for South African Revenue Service v NWK Ltd. (2011). (2) SA (67) (SCA).

Concentra (Pty) Ltd v Commissioner for Inland Revenue. (1942). CPD 509.

Constitution see South Africa. (1996).

Craddock v Zevo Finance Co Ltd. (1944). 1 All ER 566 (CA).

De Koker, A.P., \& Williams, R.C. (2011). Silke on South African Income Tax. [Lexisnexis].

Department for Business Innovation and Skills. (2012). Executive remuneration discussion paper: summary of responses. London: Author.

De Swardt, R. (2008). Do share-based payments made for the procurement of services qualify as expenditure actually incurred? De Jure, 41, 475 - 492.

Eaton, J., \& Rosen, H.S. (1983). Agency, delayed compensation and the structure of executive compensation. Journal of Finance, 38(1), 1489-1505.

Edgars Stores Ltd v Commissioner for Inland Revenue. (1988). (3) SA 876 (AD).

Eisenhardt, K.M. (1989). Agency theory: an assessment and review. Academy of Management Review, 14(1), 57-74.

Erf 3183/1 Ladysmith (Pty) Ltd and Another v Commissioner for Inland Revenue. (1996). (3) SA 942 (SCA).

Frye, M.B. (2004). Equity-based compensation for employees: firm performance and determinants. The Journal of Financial Research, 27(1), 31-54.

Gad, R., \& Strauss, J. (2011). Bad news for companies granting equity for services. Tax Ensight. Retrieved from http://www.ens.co.za/news/news_article.aspiID=560\&iType=4.

Ger, B. (2004). The problem of paying with shares. De Rebus, 61 - 62.

Hall, B.J. \& Liebman, J.B. (1998). Are CEOs really paid like bureaucrats? The Quarterly Journal of Economics, $113(3), 653-691$.

Income Tax Act 58 of 1962 see South Africa. (1962).

International Accounting Standards Board. (2012). A guide through International Financial Reporting Standards Part $A$. London: IFRS Foundation.

Institute on Taxation and Economic Policy. (2012). Tax principles: building blocks of a sound tax system. Retrieved from http://www.itepnet.org/pdf/pb9princ.pdf

ITC 1783. (2004). 66 SATC 373.

ITC 1801. (2005). 68 SATC 57.

Jensen, M.C. \& Meckling, W.H. (1976). Theory of the firm: managerial behaviour, agency costs and ownership structure. Journal of Financial Economics, 3(4), 305-360.

Joffe \& Co (Pty) Ltd v Commissioner for Inland Revenue. (1946). AD 157.

Lace Proprietary Mines Ltd v Commissioner for Inland Revenue. (1938). AD 267.

Lategan WH v Commissioner for Inland Revenue. (1926). CPD 203.

Lynn, A.D. (1976). Adam Smith's fiscal ideas: an eclectic revisited. National Tax Journal, 29(4), 369-378.

Mawani, A. (2003). Tax deductibility of employee stock options. Canadian Tax Journal, 51(3), 1230-1258.

Meyerowitz. (2006). Meyerowitz on Income Tax. Cape Town: The Taxpayer.

Musgrave, R.A. (1990). Horizontal equity once more. National Tax Journal, 43(2), 113-122.

Nasionale Pers Bpk v Kommissaris van Binnelandse Inkomste. (1986). (3) SA 549 (AD)

National Treasury. (2004). Explanatory Memorandum on the Revenue Laws Amendment Bill, 2004. Pretoria

National Treasury. (2013). 2013 Tax Statistics. Retrieved from http:/www.treasury.gov.za/publications/tax\%20statistics/2013/TStats\%202013\%20WEB.pdf

Ochberg v Commissioner for Inland Revenue. (1933). CPD 256, 6 SATC 1.

Organisation for Economic Co-operation and Development. (2005). The taxation of employee stock options. Tax Policy Studies. Paris: Author.

Osborne v Steel Barrel Co Ltd. (1942). 1 All ER 634 (CA).

Partington v The Attorney General. (1869). 21 LT 370.

Pendleton, A. (2006). Incentives, monitoring and employee stock ownership plans: new evidence and interpretations. Industrial Relations, 45(4), 753-775.

Reese, T. (1980). The politics of taxation. Quorom: Westport. 
Smith, A. (1892). An inquiry into the nature and causes of the wealth of nations. London: Routledge. (Original work published 1776)

Smith, C.W., \& Watts, R.L. (1983). The structure of executive compensation contracts and the control of management. New York: University of Rochester.

Sneed, J.T. (1965). The criteria of federal income tax policy. Stanford Law Review, 17(4), 567-613.

South Africa. (1996). Constitution of the Republic of South Africa 1996. Pretoria: Government Printer.

South Africa. (1962). Income Tax Act 58 of 1962. Pretoria: Government Printer.

South African Revenue Service. (2014). Tax Court Judgments. Retrieved from http://www.sars.gov.za/Legal/DRJudgments/Tax-Court/Pages/default.aspx

Surrey, S.S., \& Brannon, G.M. (1968). Simplification and equity as goals of tax policy. William and Mary Law Review, 9(4), 915-921.

Stanton (Inspector of Taxes) v Drayton Commercial Investment Co Ltd. (1982). 2 All ER 942 (HL).

St-Onge, S., Magnan, M., Thorne, L., \& Raymond, S. (2001). The effectiveness of stock option plans. Journal of Management Inquiry, 10(3), 250-266.

Van Eeden, R. (2011). Labat judgment may have wider implications. Cliffe Dekker Hofmeyr Press Releases. Retrieved from http:/www.cliffedekkerhofmeyr.com/en/news/press-releases/2011/labat-judgment-widerimplications.html

Van Zyl, S.P. (2012). The meaning of "expenditure" for purposes of section 11(a) and (GA) of the Income Tax Act 58 of 1962 - CSARS v Labat Africa Ltd [2011] ZASCA 157: cases. Obiter, 33(1), 186 - 192 


\section{NOTES}

